\title{
The social dimension of multi-racial advertising: Its impact on consumers' attitude
}

\author{
G.D. Johnson* \\ School of Economic and Business Sciences, Witwatersrand University, \\ Private Bag 3, Wits 2050, Republic of South Africa \\ Guillaume.johnson@gmail.com
}

Received January 2009

\begin{abstract}
Since the end of the apartheid regime, the number of advertisements casting actors from different racial backgrounds simultaneously has significantly increased. Comments about this development are multi-faceted. While some observers praise this technique as the ideal social mirror of the "new" South Africa, others criticize it as a pervasive commercial tactic. Consistent with this debate, it is important for brands to understand consumers' perceptions of multi-racial advertising. Indeed, these perceptions are also assumed to influence consumers' attitude towards the advertised brand. Based on the attribution theory, this study investigates whether South African companies, by integrating a multi-racial feature in an advertisement, create the perception amongst consumers that their advertisement is socially responsible and, in so doing, increase their brand equity. The empirical results of this study support that consumers' attitude towards a brand is significantly influenced by the extent to which they attribute a social responsibility to its advertisements. Nevertheless, it is also found that using multi-racial advertising is a necessary but not sufficient condition to generate this social attribution.
\end{abstract}

*To whom all correspondence should be addressed.

\section{Introduction}

Since 1994 and the end of the apartheid regime, the South African advertising industry has known important modifications in terms of targeting practices and rhetoric. Idioms such as the 'New South Africa', the 'Rainbow Nation' and 'Nation-Building', which were widely used by politicians, also became common terminology amongst advertisers (Sutherland, 2004). In particular, due to its racial feature, multi-racial advertising has evolved along with the radical political and social change.

The (now democratically elected) government has encouraged companies to reflect the South African racial diversity in their ownership and human resource practices as well as in the advertising of their businesses and products. As a result, the number of advertisements casting actors from different racial backgrounds (namely multi-racial or integrated advertisements) has significantly increased in the post-apartheid period.

South African advertisers maintain that the multi-racial representations within this type of advertising hold a social role that counteracts the segregated depiction of the society (Association for Communication and Advertising, 2002). Consumers who are exposed to a multi-racial advertisement might perceive this social dimension and attribute a social responsibility to the advertisement. However, while the use of multi-racial feature in advertising was initially considered as altruistic, the costs of advertising encouraged firms to consider this practice as an investment and expect a return. Thus, the chief research objective of this study is to examine how the social dimension attributed to a multi-racial advertisement influences viewers' attitude towards the brand promoted in the advertisement.

\section{Multi-racial advertising in South Africa}

During the apartheid era in South Africa, researchers such as Orpen (1975) argued that multi-racial advertising afforded South African coloured subjects the opportunity to enhance their perception of themselves, whereas "segregated advertising" (i.e. advertising including only same race actors) reinforced the government's principle of apartheid. However, in spite of these criticisms, advertisers were not totally free to design their own advertisements. Censors such as the South African Broadcasting Corporation (SABC) scrutinized their work and defined the acceptable level of integration between black and white actors. Different races could shop together but not party together, black and white children could play together in a rural setting but not an urban setting, and inter-racial "love relationships" were absolutely prohibited (Whitehead, 1983).

Thus, the advertising content had to be in accordance with the South African legislation of that period and the number of multi-racial advertisements appearing in the media was minimal. De Kock (1982) found that between 1978 and 1981 multi-racial advertisements represented about $2 \%$ of 1148 full-page advertisements in South African magazines. 
More than $88 \%$ of these advertisements were located in magazines read by the black community, whereas only $11.5 \%$ of them were located in magazines read by the whites (De Kock, 1982). Nonetheless, these policies of censure and advertising placement were consistent with the results of research which found that while white respondents considered as unacceptable a multi-racial advertising depicting an inter-racial "love relationship", black respondents were more positive than whites toward multiracial advertising (De Kock, 1982).

Towards the end of the apartheid regime, attitude changed. The influence of advertising on individuals' social behaviour and hence society started to be recognized by advertisers and consumers (Basson, 1988; Enslin, 1993). Basson (1988) pointed out that both white and black consumers and advertising agencies had a positive orientation toward the use of multi-racial television advertising. Furthermore, Basson (1988) found that both black and white consumers attributed a political dimension to the multi-racial advertising. Respondents indicated that multi-racial television advertising could contribute to an improvement in racial relations and could accelerate social integration in the country (Basson, 1988).

The governments of the "new" (i.e. post 1994) South Africa have understood the political and social dimension of multiracial advertising. In 2001, the South African Government's Parliamentary Portfolio Committee on Communication explored the need for transformation in the advertising industry. This investigation has been wide-ranging and includes issues such as advertising content, advertising agency ownership, employment practice and education (Sutherland, 2004). In accordance with the portfolio's recommendations, the Association for Communication and Advertising, which represents more than $75 \%$ of all South African advertisements, developed a 10-point statement of values for the advertising industry. Through this document, advertisers indicate their aspirations of playing an important role in the "new" South Africa (Association for Communication and Advertising, 2002). They declare wanting to "craft" a unique and meaningful South African culture and identity reflecting the diversity of South African consumers. In doing so, they desire to assist the nationbuilding in celebrating and promoting the constitutional values; such as respect for human dignity, equality and freedom. This document argues that advertisements should attempt to portray South Africa in such a way that the advertisements install a feeling of pride and belonging for all people of the country.

In order to achieve this aim, South African advertisers have changed their behaviour using more multi-racial advertisements. For instance, studies pointed out an obvious increase in the number of multi-racial advertisements consisting of children in the post-apartheid period (North, 2003; North \& Millard, 2003). Indeed, while multi-racial advertisements of this type were $5 \%$ in 1983 and $1 \%$ in 1987 , they were almost $11 \%$ in 1997 . The authors concluded that this difference confirms that advertisers have realised that their advertisements must reflect "the true nature of the new South Africa" (North \& Millard, 2003:48). Nevertheless, the authors pointed out the fact that when the black community constitutes $76 \%$ of the South African population in 1996, the $89 \%$ of advertisements representing only white children as models can be seen as disproportionate (North \& Millard, 2003). Thus, even if a step has been made in the right direction, the advertising strategies in South Africa still do not reflect the real changes which are taking place in the country (North \& Millard, 2003).

Conversely, while North and Millard (2003) praise at least the new multi-racialism, a body of research criticized the ecumenist pressure exerted by multi-racial advertising since the end of the apartheid period. According to Baliserio (1997:3), the numerous multi-racial advertisements broadcasted present "a new South Africa à la United Colours of Benetton, suspiciously amicable and homogeneous in its picture of perfect diversity". Similarly, Berger (2001:171) compared multi-racial advertising to a "fantasy world". Baliserio (1997) emphasised the incoherent fact that after the advertisements, when the news starts and crime is presented, whites and blacks continue to inhabit different worlds. Whites are behind the camera or the microphone, whereas blacks are facing the camera behind bars, being interrogated or lying wounded on the ground after a theft (Baliserio, 1997).

Saks (1997) also criticized multi-racial advertising because while it offers more pluralism, its underlying aim is to provide greater standardisation: South Africa would consume the same products as the rest of the world. In line with this, Bertelsen $(1996 ;$ 1998) pointed out that the increase in the number of black actors in the advertisements of the "new" South Africa is less about giving voice to the former dispossessed than about global consumerism and advertising itself. Bertelsen (1998) considers that these advertisements mobilise the cultural power of the South African democratic struggle by appropriating its respected signifiers and rerouting them to a vigorously propagated discourse of consumerism and the 'free market'.

In conclusion, comments about multi-racial advertising in South Africa are diverse and complex. While some observers praise the development of this technique as the ideal social mirror of the "new" South Africa, others criticize it as a pervasive commercial tool. Consistent with this debate, the present study examines whether South African companies, by integrating a multi-racial feature in an advertisement, create the perception amongst consumers that the business is socially involved. Typically, it is argued that the attribution theory (Heider, 1958; Kelley, 1967) provides a strong theoretical basis for understanding consumer perception.

\section{Attribution theory}

This theory, which is particularly helpful in understanding consumers' interpretation of brand's actions (Folkes, 1988), suggests that causal analysis is inherent in individuals' need to understand social events (Laczniak, DeCarlo, Motley \& Ramaswami, 2001). Attribution theory addresses the processes by which individuals evaluate the motives of others and explains how these perceived motives influence subsequent consumer attitudes and behaviour (Forehand \& 
Grier 2003). In advertising studies, attribution theory suggests that consumers who are exposed to an advertisement evaluate a brand according to the motives that they attribute to be the cause of the advertisement (Grewal, Gotlieb \& Marmorstein, 1994). This study argues that consumers' attributions play an important role in advertising processing, particularly when multi-racial appeals are utilized.

\section{Problem statement}

Even if some studies have considered multi-racial advertising's social role (e.g. Barban, 1969; Cox, 1970; Stern, 1999; Surlin, 1977; Whittler, 1991), little research has directly explored the implications of this social dimension for consumer response. Furthermore, these studies were concerned only with the way in which the consumer perceived multi-racial advertising in general (as opposed to a specific multi-racial advertisement). In other words, previous studies neglected to consider the perceptions of consumers toward a specific advertisement which integrated actors from multiple races. They do not consider whether the social responsibility perceived in the integration of a black actor in a specific advertisement influences its effectiveness.

This oversight may be because this social dimension is considered as merely altruistic. However, companies regard their social actions today not as "outright donations but as investments that are intended to benefit the company as well as the recipient" (Brønn \& Vrioni, 2001:209). From a marketing perspective, the firm's economic and financial benefits from social initiative have been evaluated in terms of consumers' positive product and brand attitudes (Marin \& Ruiz, 2007), also referred as customer-based brand equity (Keller, 1993).

In essence, the problem investigated in this study was whether a company, by using a multi-racial advertisement as tactic, can expect a return on its investment by strengthening its consumer-based brand equity, because of the perceived social responsibility in the advertisement.

\section{Research objective}

Multi-racial advertising is defined as a type of advertising casting actors from different racial backgrounds simultaneously. The objective of this study is to investigate whether consumers credit a specific multi-racial advertisement with social attributes and whether this attribution, in turn, influences their attitude towards the brand.

The first step of this study is to determine whether consumers consider a specific multi-racial advertisement as more socially responsible than a "segregated/mono-racial" advertisement (i.e. advertisements with only white or black actors). Then, the study examines whether viewers' race, age and education level influence the extent to which viewers attribute a social responsibility to an advertisement. Finally, the impact of the social attribution on consumerbased brand equity is examined through viewers' attitude towards the brand.

\section{The operationalisation of variables}

Three dependent variables were studied: the type of advertisement, respondents' racial group and respondents' education level. First, the type of advertisement was operationalised by three different sorts of advertisements varying in their racial composition: a multi-racial advertisement featuring black and white actors, an all-white advertisement in which all the actors are white, and an allblack advertisement featuring black actors only. In South Africa, as a cornerstone of the apartheid system, four key categories defined the population in terms of race: Africans/Blacks (79\%), Asians (2.5\%), Coloureds (9\%), and Whites (9.5\%) (Grier \& Brumbaugh, 2007; Statistics South Africa, 2005). For the purpose of this study, the independent variable of race considers only black and white demographics. The first group refers to individuals whose ancestors inhabited South African soil before the European settlement, whereas the second group consists of people of European origin (Afolayan, 2004). The education level varies between respondents completion of high school/college, bachelor or postgraduate degrees.

Two dependent variables were used, namely the social responsibility attributed to the advertisement and the attitude towards the brand. First, the social responsibility attributed to the advertisement is operationalised as the extent to which viewers see the multi-racial advertisement as representing and shaping social and racial harmony. In other words, this variable measures the extent to which they believe a particular advertisement has a positive influence on South African society. However, the consumers' social responsibility attribution may also be negatively valenced. It is acknowledged that the viewers may also be sceptical about advertisers' use of racial feature. According to Forehand and Grier (2003), attribution theory provides an appropriate basis for analyzing consumer scepticism. Indeed, attribution theory suggests that consumers attempt to understand brands' motives embedded within their actions. Consumers' scepticism may engender a more distrustful reaction toward the advertisement. On the other hand, the attitude towards the brand is operationalised as viewers' predisposition to respond in a favourable or unfavourable manner to a particular brand (Lutz, 1985:53). The attitude toward the brand is considered as a unidimensional and a mainly affective construct (MacKenzie, Lutz \& Belch, 1986).

\section{Research hypotheses}

The null hypotheses tested in this study were:

$\mathrm{HO}^{1}$ : The type of advertisement does not influence the extent to which viewers attribute a social responsibility to the advertisement.

$\mathrm{HO}^{2}$ : The interaction between the type of advertisement and the race of the viewers does not influence the extent to which viewers attribute a social responsibility to the advertisement.

$\mathrm{HO}^{3}$ : The interaction between the type of advertisement and the age of the viewers does not influence the extent to 
which viewers attribute a social responsibility to the advertisement.

$\mathrm{HO}^{4}$ : The interaction between the type of advertisement and the level of education of the viewers does not influence the extent to which viewers attribute a social responsibility to the advertisement.

$\mathrm{HO}^{5}$ :The extent to which viewers attribute a social responsibility to the advertisement does not influence viewers' attitude towards the brand.

\section{Research design and methodology}

The design of the experiment involved a three types of advertising (i.e. all-black, all-white or multi-racial) between subjects factorial design. This study investigates the reactions of a community sample of adults rather than a sample of students, who are assumed to be more tolerant (Whittler \& Mimeo, 1991). Although student samples have been used in previous multi-racial advertising research (e.g. Forehand \& Deshpandé, 2001), they can reduce the external validity of the study and therefore restrict the generalisability of the results. Altogether five hundred and five adults (237 blacks and 268 whites) ranging from 18 to 77 years were randomly selected (non-probability sampling technique) from the Eastern Cape province.

The demographic characteristics of subjects fit those of the intended target market for the advertisement product evaluated. The gender, race, age and level of education of the sample are outlined in Table 1.

The stimuli consisted of full-colour photographic advertisements for a fictitious brand. The product advertised was a pen because it does not possess any cultural stereotype and it is not race or gender-related. In order to control for potential threats to internal validity and prior brand learning, the brand name used was fictitious. The advertisement was embedded in a press article (which did not address any cultural issue), selected from a TV magazine which does not target a specific cultural group, in order to make the experiment as realistic as possible and to reach a better external validity (Brown \& Stayman, 1992).
This study used digital techniques to control the vast majority of extraneous variables present in an advertisement. First, it was decided that both genders should be used within the advertisements with the intention of controlling gender bias, which may have been present among the study's participants (Simpson, Snuggs, Christiansen \& Simples, 2000). Moreover, in order to guarantee that actors' attractiveness was equal for each actor present in the same picture (i.e. a model was not over-liked when another one was under-liked), a pre-test sample rated the photographs of the actors separately. Thus, three identical advertisements were created in which only the race of the actors differed.

The survey was initially presented as a research project about management. Participants completed the study individually with the author. Participants were randomly assigned to one of the three advertisements embedded in the press article. After reading the article for about 5-7 minutes, participants were given the questionnaire booklet to complete. The items used to measure the social responsibility attributed to the advertisement (i.e. this advertisement is useful to society; this advertisement might help things progress in the society; this advertisement transmits good values in the society; this advertisement contributes something to society) were linked to a 7-point Likert-type scale. The internal consistency reliability of this measure was respectable, with the scale attaining Nunnaly's (1978) suggested Cronbach's alpha of 0,70 or higher $(\alpha=$ 0,9071). Respondents were also asked to provide their attitude towards the brand using MacKenzie et al.'s (1986) 7-point semantic differential scale: favourable/unfavourable, $\operatorname{good} /$ bad, wise/foolish $(\alpha=0,9214)$.

\section{Empirical results}

The results of the experiment are presented and discussed according to the hypotheses presented earlier. A series of one-way or two-way analyses of variance (ANOVA) for all hypotheses are given below. Only significant main effects and interactions were mentioned in the results. The results for hypotheses $\mathrm{HO}^{1}, \mathrm{HO}^{2}, \mathrm{HO}^{3}$ and $\mathrm{HO}^{4}$ are presented in Table 2 .

Table 1: Demographic information of the sample

\begin{tabular}{|c|c|c|c|}
\hline & Black respondents & White respondents & TOTAL \\
\hline \multicolumn{4}{|l|}{ Gender } \\
\hline Male & 123 & 96 & 219 \\
\hline Female & 114 & 172 & 286 \\
\hline \multicolumn{4}{|l|}{ Age } \\
\hline 18-29 years & 99 & 120 & 219 \\
\hline 26-39 years & 112 & 88 & 200 \\
\hline $40-64$ years & 26 & 60 & 86 \\
\hline \multicolumn{4}{|c|}{ Level of Education } \\
\hline High School/college & 140 & 66 & 206 \\
\hline Bachelor & 38 & 30 & 68 \\
\hline Postgraduate & 59 & 172 & 231 \\
\hline TOTAL & 237 & 268 & 505 \\
\hline
\end{tabular}


Table 2: Hypotheses $\mathrm{HO}^{1}$ to $\mathrm{HO}^{4}$ - ANOVA

\begin{tabular}{|c|c|c|c|c|c|}
\hline \multirow{2}{*}{\multicolumn{2}{|c|}{$\begin{array}{l}\text { Dependent variable: } \\
\text { Social responsibility attributed to the advertisement }\end{array}$}} & \multicolumn{4}{|c|}{ ANOVA } \\
\hline & & $\mathbf{F}$ & Df & Sig. & Eta $^{2}$ \\
\hline $\mathrm{HO}^{1}$ & Type of advertisement & 0,438 & 2,502 & 0,646 & 0,002 \\
\hline $\mathrm{HO}^{2}$ & Type of advertisement $\times$ viewers' race & 1,582 & 2,499 & 0,207 & 0,006 \\
\hline $\mathrm{HO}^{3}$ & Type of advertisement $\times$ viewers' age & 0,279 & 4,496 & 0,891 & 0,002 \\
\hline $\mathrm{HO}^{4}$ & Type of advertisement $\times$ viewers' education level & 2,760 & 4,496 & $0,027^{*}$ & 0,022 \\
\hline
\end{tabular}

\section{One-way ANOVA: the type of advertisement}

$\mathrm{HO}^{1}$ assumed that the type of advertisements does not influence the extent to which viewers attribute a social responsibility to the advertisement. Table 2 reports that there is not significant interaction between the type of advertisement and viewer's social attribution, $F(2,502)=$ $0,438, p>0,05$. A closer examination of the means stresses that viewers attributed more social responsibility to the multi-racial advertisement $(\mathrm{M}=3,850)$ than to either the allblack $(\mathrm{M}=3,788)$ or all-white $(\mathrm{M}=3,687)$ advertisements. However, the differences between the means were nonsignificant and $\mathrm{HO}^{1}$ was accepted.

Two-way ANOVA: the type of advertisement and race

$\mathrm{HO}^{2}$ proposed that the interaction between the type of advertisement and viewers' race does not influence the extent to which viewers attribute a social responsibility to advertising. Table 2 shows that the interaction between the type of advertisement and viewers' race did not significantly influence viewers' social attribution $F(2,499)=1,582, \mathrm{p}$ > 0,05 . Indeed, black viewers $(\mathrm{M}=4,604)$ attribute significantly more social responsibility to any type of advertisement than white viewers $(\mathrm{M}=3,099, \mathrm{p}<0,05)$. Hence, $\mathrm{HO}^{2}$ was accepted.

Two-way ANOVA: the type of advertisement and age

$\mathrm{HO}^{3}$ stated that the interaction between the type of advertisement and viewers' age does not influence the extent to which viewers attribute a social responsibility to the advertisement. Table 2 reports that this interaction did not influence viewers' social attribution $F(4,496)=0,279$, $p$ $>0,05$. Consequently, $\mathrm{HO}^{3}$ was accepted.

Two-way ANOVA: the type of advertisement and level of education

$\mathrm{HO}^{4}$ assumed that the interaction between the type of advertisement and viewers' education level does not influence the extent to which viewers attribute a social responsibility to the advertisement. However, Table 2 reveals that the type of advertisement and viewers' education level had a significant effect $(p<0,05)$ on viewers' social attribution and $\mathrm{HO}^{4}$ was rejected. The reported difference was followed up with the post-hoc Scheffé test, displayed in Table 3.

Table 3 reveals that viewers with a high school/college degree $(M=4,422)$ attributed more social responsibility to the 3 advertisements than viewers with a bachelor $(\mathrm{M}=$ $3,882, p<0,05)$ or a postgraduate degree $(M=3,233, p<$ $0,05)$. Similarly, viewers with a bachelor degree $(M=3,882)$ attributed more social responsibility to the 3 advertisements than viewers with a postgraduate degree $(\mathrm{M}=3,233, \mathrm{p}<$ $0,05)$.

Furthermore, Table 3 reports that exposed to the multi-racial advertisement viewers with a high school/college degree attributed more social responsibility to the multi-racial advertisement $(M=4,381)$ than viewers with a bachelor ( $M$ $=4,216, \mathrm{p}<0,05)$ or a postgraduate degree $(\mathrm{M}=3,285, \mathrm{p}<$ $0,05)$. Similarly, viewers with a bachelor degree $(M=4,216)$ attributed more social responsibility to the multi-racial advertisement than viewers with a postgraduate diploma (M $=3,285, \mathrm{p}<0,05)$.

Conversely, Table 3 shows that the differences in social attribution between viewers with a bachelor and postgraduate degree were not statistically significant when those viewers were exposed to an all-black $(p>0,05)$ or allwhite $(p>0,05)$ advertisement. On the other hand, both of these groups attributed less social responsibility to all-white and all-black advertisements than the viewers with a high school/college degree.

\section{Regression linear: social attribution on consumer- based brand equity}

The last hypothesis examined the influence of the social attribution on consumer-based brand equity. In other words, $\mathrm{HO}^{5}$ assumed that the extent to which viewers attribute a social responsibility to an advertisement does not influence viewers' attitude towards the brand. A regression analysis, presented in Table 4, tests this hypothesis.

The result of the linear regression (see Table 4) shows a significant relationship between the social responsibility attributed to the advertisement and the attitude towards the brand $F(1,503)=225,646, p<0,05$. Typically, viewers' social attribution explained $31 \%$ of the variance of their attitude towards the brand. Hence $\mathrm{HO}^{5}$ is rejected. 
Table 3: Hypotheses $\mathrm{HO}^{4}$ - Scheffé post-hoc test

\begin{tabular}{|c|c|c|c|}
\hline & \multicolumn{3}{|c|}{ Scheffé Test } \\
\hline & High school/ college & Bachelor & Postgraduate \\
\hline $\begin{array}{l}\text { Mean score of the social responsibility attributed to the } 3 \\
\text { advertisements }\end{array}$ & 4,422 & 3,882 & 3,233 \\
\hline \multicolumn{4}{|l|}{ High school/college } \\
\hline Bachelor & $0,025^{*}$ & & \\
\hline Postgraduate & $0,000 *$ & $0,004 *$ & \\
\hline $\begin{array}{l}\text { Mean score of the social responsibility attributed to the multi- } \\
\text { racial advertisement }\end{array}$ & 4,381 & 4,216 & 3,285 \\
\hline \multicolumn{4}{|l|}{ High school/college } \\
\hline Bachelor & 0,809 & & \\
\hline Postgraduate & $0,000^{*}$ & $0,001 *$ & \\
\hline $\begin{array}{l}\text { Mean score of the social responsibility attributed to the all-black } \\
\text { advertisement }\end{array}$ & 4,426 & 3,355 & 3,356 \\
\hline \multicolumn{4}{|l|}{ High school/college } \\
\hline Bachelor & 0,071 & & \\
\hline Postgraduate & $0,024 *$ & 1,000 & \\
\hline $\begin{array}{l}\text { Mean score of the social responsibility attributed to the all-white } \\
\text { advertisement }\end{array}$ & 4,737 & 2,625 & 3,031 \\
\hline \multicolumn{4}{|l|}{ High school/college } \\
\hline Bachelor & $0,009^{*}$ & & \\
\hline Postgraduate & $0,000^{*}$ & 0,828 & \\
\hline
\end{tabular}

Table 4: Hypothesis $\mathrm{HO}^{5}$ - Linear regression

\begin{tabular}{cccccc}
\hline Dependent variable: & \multicolumn{4}{c}{ Linear regression } \\
\cline { 2 - 5 } Attitude towards the brand & $\mathrm{F}$ & $\mathrm{Df}$ & Sig. & $\mathrm{R}$ \\
\hline $\begin{array}{c}\text { Social responsibility attributed to the } \\
\text { advertisement }\end{array}$ & 225,646 & 1,503 & $0,000^{*}$ & 0,556 & 0,310 \\
\hline
\end{tabular}

$*=\mathrm{p}<0,05$

\section{Conclusion}

The results of this study provided some important insights in the field of multi-racial advertising in South Africa. First, this research points out that the attitude of the South African consumers towards a brand is significantly influenced by the extent to which they attribute a social responsibility to its advertisements $\left(\mathrm{HO}^{5}\right)$. Nevertheless, the reported empirical results have shown that the proposed null hypotheses $\mathrm{HO}^{1}$, $\mathrm{HO}^{2}, \mathrm{HO}^{3}$ could not be rejected. The main implication is that, unlike the general rhetoric amongst South African advertisers (see Association for Communication and Advertising, 2002), the way consumers attribute a social responsibility to an advertisement broadcasting actors from different races is not simple.

This study confirmed the difficulty for advertisers to change attitudes and increase brand equity through social attribution. Although it is acknowledged that leveraging social responsibility to obtain a commercial return is possible, the integration of the scepticism which negatively valences the construct social responsibility attributed to the advertisement shows, in accordance with the attribution theory and numerous studies, that consumer reactions to social initiatives are multi-faceted and incorporate a duality of motives (e.g. Brønn \& Vrioni, 2001; Forehand \& Grier, 2003). Typically, it has been found that white viewers and highly-educated viewers are significantly more sceptical towards advertising than black viewers and high school/college educated viewers, respectively.

\section{Limitations of the study}

The first limitation which can be addressed to this study is the fact that respondents were exposed to only one fictitious product advertisement (i.e. a pen). Consequently, even if this choice afforded to control the internal validity required by the newness of this type of study in the South African context, any generalization made from our result may be premature since consumers often provide responses that are product-specific. Further research needs to investigate consumers' responses to a broader panel of products from fictitious and real brands.

The second limitation concerns the choice of the medium. Television with its highly complex visual, aural, motion and message effects would have been particularly useful in portraying the detail and nuance of racial interactions (Pitts, Whalen, O'Keefe \& Murray, 1989:313). Thus, television advertising would have been more effective in the study of 
racial interaction than print advertising, which is considered more "static" (Pitts et al., 1989). Nevertheless, the use of print advertising was justified by the complexity of the experimental procedure undertaken. The main objective of this study was to analyse the impact of a multi-racial advertisement on advertising effectiveness. Televised advertisements do not isolate the variable of multi-racial casting. Other elements such as music and colours could bias the experiment. To control these elements, a multiracial televised advertisement could have been created. However, without possessing the necessary skills, this advertisement could have been perceived as an amateur production. Conversely, print advertisements are easier to create and manipulate. Moreover, the use of televised advertisements would have made the questionnaire administration more laborious. The interviewers would have been constrained by having to use a television during their interviews. For these reasons, the realisation of a fictitious print advertisement, embedded in a press article, was chosen.

Furthermore, this study focuses on only two racial groups: black and white actors/consumers. Even if this choice is justified by the history of South Africa, these population groups are not homogenous themselves. Xhosa, Zulu, Pedi, Ndebele and Sotho black consumers on the one hand, and English- and Afrikaans-speaking consumers on the other hand, might have different reactions to the multi-racial advertisement. For instance, Enslin (1993) found that Afrikaans-speaking respondents rated racially integrated advertisements less favourably than their English-speaking counterparts, and had a more positive attitude towards photographs with models of one race only. Further research needs to investigate the social attribution of consumers from other racial and cultural groups.

\section{Managerial implications}

Despite the potential limitations the managerial implications resulting from this study are rich for South African advertisers. The focus of this study on specific advertisements, rather than multi-racial advertising in general, has important implications for practitioners. Although anecdotal evidence may suggest that incorporating actors of different races will generate social attribution towards the advertisement and then increase brand equity, this study shows that this is a complex process. Including actors of different races in the same advertisement is a necessary but not sufficient condition to generate social attribution. Consequently, advertisers should primarily focus on the level of interaction and complicity between the actors and then determine their racial group.

\section{References}

Afolayan, F. 2004. Culture and customs of South Africa. Wesport: Greenwood Press.

Association for Communication and Advertising. 2002. Portfolio committee on communications hearings into transformation of the advertising and marketing industry. [online] URL:

http://www.gcis.gov.za/docs/portcom/02aca html.
Baliserio, I. 1997. 'Simunye? Searching for nationhood in post-apartheid South Africa', Communicare, 16(1):1-18.

Barban, A.M. 1969. 'The dilemma of integrated advertising', Journal of Business of the University of Chicago, 42(October):477-496.

Basson, A.F. 1988. 'Reklameplanning van veelrassige tlevisieadvertensies: 'n Kommunikasekundige perspektief'. Unpublished Ph.D. thesis. University of Free State at Bloemfontein, South Africa.

Berger, G. 2001. 'De-racialisation, democracy and development: transformation of the South African media 1994-2000'. In Tomaselli, K \& Dunn, H. (Eds.). Media, democracy and renewal in Southern Africa. Colorado Springs: International Academic Publishers.

Bertelsen, E. 1996. 'Selling change: Advertisements for the 1994 South African election', African Affairs, 95:225-252.

Bertelsen, E. 1998. Ads and amnesia: black advertising in the new South Africa. In Nuttall, S. \& Coetzee, C. (Eds.). Negotiating the past: The making of memory in South Africa. Cape Town: Oxford University Press.

Brønn, P.S. \& Vrioni, A.B. 2001. 'Corporate social responsibility and cause-related marketing: An overview', International Journal of Advertising, 20(2):207-222.

Brown, S.P. \& Stayman, D.W. 1992. 'Antecedents and consequences of attitude toward the ad: a meta-analysis', Journal of Consumer Research, 19:34-51.

Cox, K.K. 1970. 'Social effects of integrated advertising', Journal of Advertising Research, 10(2):41-44.

De Kock, C.I. 1982. 'The acceptability level of black and white models in advertisements, 1981'. Research Report No. 97. Bureau for Market Research. Pretoria: University of South Africa.

Enslin, C. 1993. 'The creative approach of the South African advertising industry towards the black consumer', Communicare, 12(2):21-35.

Folkes, V.S. 1988. 'Recent attribution research in consumer behavior: A review and new directions', Journal of Consumer Research, 14(March):548-565.

Forehand, M.R. \& Deshpandé, R. 2001. 'What we see makes us who we are: Priming ethnic self-awareness and advertising response', Journal of Marketing Research, 38(3):336-349.

Forehand, M.R. \& Grier, S.A. 2003. 'When is honesty the best policy? The effect of stated company intent on consumer skepticism', Journal of Consumer Psychology, 13(3):349-356.

Grewal, D., Gotlieb, J. \& Marmorstein, H. 1994. 'The moderating effects of message framing and source 
credibility on the price-perceived risk relationship', Journal of Consumer Research, 21(June):145-153.

Grier, S. A. \& Brumbaugh, A. M. 2007. 'Compared to whom? The impact of status on third person effects in advertising persuasion in a South African context', Journal of Consumer Behaviour, 6(Jan-Feb):5-18.

Heider, F. 1958. The psychology of interpersonal relations. New York: Wiley.

Keller, K.L. 1993. 'Conceptualizing, measuring, and managing customer-based brand equity', Journal of Marketing, 57(January):1-22.

Kelley, H.H. 1967. 'Attribution theory in social psychology'. In Levine, D. (Ed.). Nebraska symposium on motivation. Lincoln: University of Nebraska Press.

Laczniak, R.N., DeCarlo, T.E., Motley, C.M. \& Ramaswami, S.N. 2001. 'Consumers' responses to negative word-of-mouth communication: An attribution theory perspective', Journal of Consumer Psychology, 11(1):57-73.

Lutz, R.J. 1985. 'Affective and cognitive antecedents of attitude toward the ad: A conceptual framework'. In Alwitt, L. \& Mitchell, A. (Eds.). Psychological processes and advertising effects. Hillsdale, NJ: Lawrence Erlbaum Associates.

MacKenzie, S.B., Lutz, R.J. \& Belch, G.E. 1986. 'The role of attitude toward the ad as a mediator of advertising effectiveness: A test of competing explanations', Journal of Marketing Research, 23:130-143.

Marin, L. \& Ruiz, S. 2007. 'I need you too! Corporate identity attractiveness for consumers and the role of social responsibility', Journal of Business Ethics, 71: 245-260.

North, E. 2003. 'The role portrayed by children in South African magazine advertising: A longitudinal study', Communicare, 22(1):58-79.

North, E. \& Millard, S. 2003. 'Children and race in South African magazine advertising: Pre- and post-apartheid', Ecquid Novi, 24(1):37-54.

Nunally, J. 1978. Psychometric theory (2 ${ }^{\text {nd }}$ Edition.). NewYork: McGraw-Hill.

Orpen, C. 1975. 'Reactions to black and white models', Journal of Advertising Research, 15(5):75-79.

Pitts, R.E., Whalen, J. D., O’Keefe, R. \& Murray, V. 1989. 'Black and white response to culturally-targeted television commercials: A values-based approach', Psychology \& Marketing, 6(4):311-328.

Saks, L. 1997. 'Some-where over the rainbow: Theorizing the endless deferral of identity in South Africa', Communicare, 16(1):70-85.
Simpson, E.M., Snuggs, T., Christiansen, T. \& Simples, K.E. 2000. 'Race, homophily, and purchase intentions and the black consumer', Psychology \& Marketing, 17(10):877889.

Statistics South Africa. 2005. 'Achieving a Better Life for All: Progress between Census 96 and Census 2001'. [online] URL: http://www.statssa.gov.za/Publications/Report-03-0216/Report-03-02-16.pdf.

Stern, B.B. 1999. 'Gender and multicultural issues in advertising: Stages on the research highway', Journal of Advertising, 17(Spring):1-9.

Surlin, S.H. 1977. 'Authoritarian advertising executives and the use of black models in advertising: Implications for racial relations', Journal of Black Studies, 8(1):105-116.

Sutherland, I. 2004. 'Paradigm shift: The challenge to graphic design education and professional practice in postapartheid South Africa', Design Issues, 20(2):51-60.

Whitehead, M. 1983. 'Censors vet all ad mixing', Sunday Tribune, 3 April, p. 4.

Whittler, T.E. 1991. 'The effects of actors' race in commercial advertising: Review and extension', Journal of Advertising, 20(1):54-60.

Whittler, T.E. \& DiMeo, J. 1991. 'Viewers' reactions to racial cues in advertising stimuli', Journal of Advertising Research, 31(December):37-46. 